DOI: $10.11649 / a .1672$

Article No.: 1672

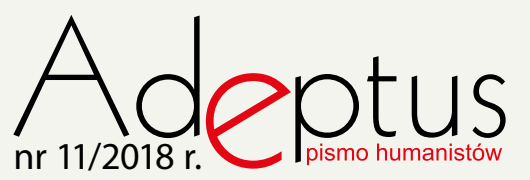

Anna Zawadzka, doktor socjologii. Adiunkt w Instytucie Slawistyki Polskiej Akademii Nauk. Badania Anny Zawadzkiej koncentrują się na wzorach polskiej kultury dominującej, ze szczególnym uwzględnieniem antysemityzmu i antykomunizmu, a także proponowanych w jej obrębie tożsamości płciowych. Obecnie pracuje nad historyczno-społeczną analizą stereotypu „żydokomuny" w polsko-amerykańskiej perspektywie porównawczej. e-mail: annazawadzka@poczta.fm

\title{
Anna Zawadzka
}

\section{Pijąc wódkę z antysemitami. Case study „relacji polsko-żydowskich” współcześnie}

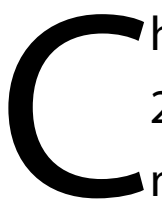

hciałabym zdać relację z pewnego ciągu zdarzeń, które miały miejsce między 31 grudnia 2016 r. a 6 stycznia 2017 r. Zdarzeń o charakterze lokalnym, a wielu powiedziałoby także: natomiast jako symptomatyczne case study, na przykładzie którego widać funkcjonowanie antysemityzmu w polskiej kulturze dzisiaj i - co może bardziej istotne - blokady, na jakie napotyka jego problematyzowanie. Omówię te zdarzenia jako swoisty spektakl, podczas którego określone podmioty wchodziły w wybrane lub w jedyne dostępne im role. Zaproponuję także, by na zdarzenia te spojrzeć przez pryzmat wybranych elementów polskiej historii.

\section{Opis wydarzeń}

3 stycznia 2017 roku autorka bloga "Gburrek.pl” opisała zdarzenie, które miało miejsce w nocy z 31 grudnia na 1 stycznia. Ponieważ tekst ten zapoczątkował lawinę reakcji, przytaczam go w całości. Tytuł tekstu to: „Katolicyzm” po polsku. Jak zostaliśmy zaatakowani w centrum Warszawy w Cafe Foksal. Pod tytułem znajduje się zastrzeżenie: „Tekst jest 
krytyką postawy nietolerancji, nie zaś wyznania (tytułowe słowo katolik zostało celowo wzięte w cudzysłów)."

Kilka godzin wcześniej przywitaliśmy z partnerem i inną parą Nowy Rok. Siedzieliśmy w czwórkę za barem przypadkowo wybranego pubu i rozmawialiśmy, czasami wstawaliśmy, żeby zatańczyć. Rodzina jednego z nas od wielu lat mieszka w Izraelu i dzień przed opisywanym wydarzeniem nasz przyjaciel właśnie stamtąd wrócił. Prywatna rozmowa, nie oscylująca wokół kontrowersji, tematyki politycznej, ani religijnej, naturalnie potoczyła się w kierunku żydostwa. Kiedy z ust kolegi padły słowa, że znanych mu Żydów ceni za ich pracowitość, zaatakowano nas po raz pierwszy. Na razie słownie. - Możecie rozmawiać sobie gdzieś indziej na takie tematy? Ja jestem katoliczką i sobie nie życzę! - krzyknęła do nas barmanka, która przez ostatnią godzinę obsługiwała naszą grupę bez najmniejszego zgrzytu. Oniemieliśmy. Spojrzeliśmy po sobie z niedowierzaniem, ale nie chcąc psuć reszty wieczoru odpowiedzieliśmy, że rozmowa jest prywatna, nikogo w niej nie obrażamy, także uwagę mamy zamiar uznać za niebyłą. To nie spodobało się pani zza baru. Zażądała, żebyśmy opuścili lokal. Nie mieliśmy takiego zamiaru. Rozgniewana kobieta zaczęła nas obrażać-«Leczcie się na głowę!», «Zapraszam na Sobieskiego!» (przyp. Warszawski Instytut Psychiatrii), «Lećcie do Michnika!». Kiedy zażą daliśmy zmiany tonu, zagroziła wyprowadzeniem z lokalu i wezwaniem policji. Nie zrobiła tego, za to przy barze pojawili się jej koledzy. Wywiązała się bójka. Widząc jak mój partner jest duszony, chwyciłam za telefon i wybierając numer 112 podbiegłam do stolika obok prosząc o nazwę i adres lokalu. Klientami pubu o tej porze okazali się jednak głównie znajomi barmanki (później słyszałam jak wołają ją po imieniu), którzy... uśmiechając się ironicznie odpowiedzieli - A skąd mamy wiedzieć?

Wybiegłam na zewnątrz, odczytałam adres i wezwałam policję. Po kilku minutach moi bliscy wyszli z lokalu pobici. Policja przyjechała po trzydziestu minutach.

To wydarzenie uświadomiło mi kilka smutnych prawd, które do tej pory, wydawało mi się, że mnie nie dotyczą.

- We własnym kraju, w miejscu publicznym, mogę zostać zaatakowana za prywatne, nieagresywne, nieobraźliwe dla nikogo poglądy, wypowiedziane podczas prywatnej rozmowy.

- Mogę wezwać policję, ale zanim przyjedzie, mogę stracić zdrowie.

Mam powody martwić się o przyszłość mojego dziecka. Bo co jeśli w tak rozumiejącym katolicyzm społeczeństwie przyjdzie mu dorastać.

(„„«Katolicyzm» po polsku. Jak zostaliśmy zaatakowani w centrum Warszawy przez obsługę Cafe Foksal", 2016).

Cafe Foksal to kawiarnia w turystycznym centrum Warszawy, przy pełnej barów, restauracji i klubów ulicy Foksal. Jednej z nielicznych ulic Warszawy, na której lokale otwarte są także nocą. 
Blog „Gburrek.pl”, na którym ukazał się tekst, nie ma charakteru aktywistycznego ani interwencyjnego. Wpisy na blogu dotyczą spraw mody, urody, diety, wychowania dziecka, pracy w korporacji, relacji intymnych. Bloga prowadzi' osoba, która przedstawia się następująco: „Mam na imię Karolina, mam trzydzieści dwa lata. Jestem pracującą mamą trzylatka. Razem z jego tatą i naszym psem mieszkamy pod Warszawą." Sądząc po wpisach, autorka bloga jest osobą z wyższym wykształceniem, należy do klasy średniej, prowadzi styl życia wskazujący na zamożność i wysoki kapitał kulturowy.

Blog Gburrek.pl ma funpage na facebooku, który subskrybuje niecałe 3000 osób, tymczasem w ciągu zaledwie kilkunastu godzin wokół tego tekstu rozpętała się burza. Najpierw sprawa rozgrywała się na Facebooku. 3 stycznia powstało wydarzenie o nazwie: „Bojkot Cafe Foksal 2017 - dość przemocy i antysemityzmu”. Uczestnictwo zadeklarowało 886 osób. Dzień później powstało wydarzenie: „W obronie Cafe Foksal - STOP obrażaniu chrześcijan w Warszawie". Udział w nim zadeklarowały 223 osoby. 4 stycznia swoje oświadczenie opublikowała na Facebooku właścicielka klubu, Anna Żelezik. Przytaczam je w całości:

W związku z pojawieniem się w mediach społecznościowych relacji i ocen związanych ze zdarzeniem mającym miejsce w Noc Sylwestrową konieczne jest kilka słów wyjaśnienia. Cafe Foksal od 24 lat swojego istnienia jest miejscem otwartym na gości o różnym pochodzeniu, wyznaniu i przekonaniach. Pomimo tego do tej pory w Lokalu nie doszło nigdy do aktu przemocy fizycznej ani słownej. Naszymi gośćmi są osoby z różnych środowisk, co stwarzało zawsze warunki dla dialogu i wymiany poglądów [wszystkie podkreślenia: AZ]. Mając na celu zapewnienie gościom ochrony cennych dla nich wartości Cafe Foksal dba o klimat sprzyjający swobodzie sumienia i wyznania. Dlatego też personel nie pozostał w Noc Sylwestrową obojętny na zachowanie kilkuosobowej grupy gości godzące w uczucia religijne Chrześcijan i upomniał ich, na co zareagowali oni agresywnie. Niestety relacje w mediach społecznościowych przedstawiają nieprawdziwy obraz zdarzenia, przypisując mu podłoże, które odwołując się do wrażliwości społecznej wzbudza niezwykle silne emocje. Kawiarnia Cafe Foksal nigdy nie pochwalała antysemityzmu ani innych ksenofobicznych postaw, dlatego z całą stanowczością odrzuca krzywdzące i nieprawdziwe zarzuty, które godzą w dobre imię Lokalu i nie dają się w żaden sposób powiązać z sytuacją, która miała miejsce z Noc Sylwestrową. Jednocześnie Cafe Foksal pragnie zapewnić, że nie ustanie w wysiłkach na rzecz zapewnienia swoim gościom poczucia bezpieczeństwa i warunków wolości od wszelkich przejawów agresji na jakimkolwiek tle, w tym także o podłożu religijnym lub światopoglądowym.

(Bernaciak \& Zimny, 2017)

\footnotetext{
${ }^{1}$ Nie mam pewności, czy blog jeszcze istnieje. W dniu 04.11.2017 witryna była niedostępna.
} 
Publikacji tego oświadczenia towarzyszyła relacja mężczyzny, który określił się mianem „świadka zdarzenia”. Oto, co świadek ów opublikował na Facebooku i co przedrukowały media:

Czteroosobowa grupa dwie kobiety i dwóch mężczyzn siedziało przy barze 5 godzinę. Zadowolona z siebie grupa [wszystkie podkreślenia: AZ] pod wpływem alkoholu zaczęła głośno rozmawiać na temat wyższości religii judaistycznej nad katolicką. Podczas tej rozmowy nazwali najświętszą Panienkę, delikatnie mówiąc kobietą lekkich obyczajów. Te wątpliwości rozszerzali również na boskie pochodzenie Chrystusa. Podkreślali wyższość religii żydowskiej nad katolicką. Barmanka zwróciła im uwagę, że nie są tutaj sami i żeby przestali w taki sposób mówić bo mogą sprawić przykrość innym a na pewno jej, gdyż sama jest katoliczką. W tym momencie jeden z uczestników biesiady, dokładnie partner życiowy blogerki, która napisała te oszczerstwa, rzucił w barmankę jakimś przedmiotem. Barmanka powiedziała, że nie toleruje takiego zachowania i poprosiła o opuszczenie lokalu. Towarzystwo odmówiło. Dwóch klientów lokalu poprosiło państwa o to samo co barmanka. Naprawdę w sposób kulturalny, nie padło ani jedno przekleństwo ani jedna groźba po za informacją, że zostanie zawiadomiona policja. Podczas tej rozmowy męska część biesiadników rzuciła się na klienta stojącego w obronie barmanki. Drugi agresor został obezwładniony i przytrzymany przez drugiego obrońcę. Kiedy szamotanina się zakończyła i drugi agresor został puszczony, towarzystwo blogerki znowu przypuściło atak... Tym razem rzucają kuflami trafiając przy tym barmankę i jedną z klientek. Sytuacja wewnątrz lokalu została opanowana, agresorzy zostali wypchnięci na zewnątrz i nie stała im się przy tym krzywda. Towarzystwo blogerki odgrażało się przy tym, że ma kontakty z Gazetą Wyborczą i «załatwi» lokal. Wydawać by się mogło, że to koniec.. ale nie. Na zewnątrz rzucali jeszcze w szyby lokalu metalową popielniczką i innymi przedmiotami. Opatrzność, Tej którą obrażali sprawiła, że nie stała się krzywda podczas próby wybicia szyb w lokalu przez blogerkę i jej towarzystwo. Potem przyjechała policja.

(Bernaciak \& Zimny, 2017)

\section{Trzy odwrócenia, dwa konteksty}

Temat podjęły media lokalne, a także niektóre media ogólnopolskie. W dniach 2-5 stycznia w kilkunastu gazetach - głównie o charakterze centrowym - ukazały się materiały poświęcone "zadymie" w Cafe Foksal. Głos zabrali internauci obficie komentując sprawę. W ich wypowiedziach początkowo dominowała opinia, że autorka bloga wszystko zmyśliła, żeby stać się sławną. W materiałach medialnych przez pierwsze dwa dni dominował ton: „sprzeczne 
relacje" oraz "słowo przeciwko słowu". Trzeciego dnia - po oświadczeniach właścicielki klubu i świadka - media pochyliły się ze współczuciem nad Cafe Foksal. W gazecie "Metro Warszawa" już 4 stycznia ukazał się artykuł pod znaczącym tytułem: Seria nienawistnych telefonów po awanturze w Cafe Foksal. Poszło o rozmowę o Żydach (Bet \& Jankowska, 2017). Sprawa została przedstawiona jako pełna przemocy i nienawiści nagonka na bar. „Ludzie wylali wiadro pomyj na obsługę kawiarni, w sieci już dokonano linczu na Cafe Foksal" pisały dziennikarki. Gazetę tę wydaje polski koncern medialny „Agora”, wydawca "Gazety Wyborczej”. Wspominam o tym, bo status "Gazety Wyborczej” jest istotny dla sprawy. Najpierw jednak podsumujmy trzy odwrócenia zdarzeń, z którymi mamy tutaj do czynienia.

Odwrócenie pierwsze: przemoc, do jakiej doszło w Cafe Foksal, miała charakter nie antysemicki, lecz anty-chrześcijański. Osoby, które twierdzą, że zostały obrażone i doświadczyły przemocy antysemickiej, w istocie same obrażały i były agresywne, a swoją agresję kierowały celowo wobec chrześcijan. Goście obrażali Matkę Boską, mówili o wyższości judaizmu nad chrześcijaństwem, a następnie fizycznie zaatakowali barmankę. To ci, którzy reprezentują Żydów, byli wrodzy i agresywni. Katolicy tylko się bronili.

Odwrócenie drugie: to nie zachowanie autorki bloga - czyli najpierw wezwanie policji, a potem opis zdarzenia - było motywowane dbałością o tolerancję, otwartość i multikulturowość (kariera tych pojęć to temat na osobną dyskusję), lecz reakcja barmanki. W swoim oświadczeniu właścicielka baru podkreślała, że barmanka słusznie i odważnie stanęła w obronie gnębionych i obrażanych - czyli chrześcijan. Chrześcijanie zostali tu przedstawieni jako wymagająca ochrony mniejszość.

Odwrócenie trzecie: po wydarzeniu za jego ofiarę uznano Cafe Foksal, jej obsługę i jej właścicielkę, za sprawcę natomiast - osobę, która to zdarzenie opisała. Przemoc antysemicka w Cafe Foksal zniknęła z pola widzenia. W jej miejsce pojawiła się nagonka na Cafe Foksal, rozpętana na skutek fałszywych oskarżeń.

Mamy tu więc do czynienia z mechanizmem obwiniania ofiary-zastosowanym ex post, w opisie zdarzenia, gdy sprawcy podawali swoje motywy i przedstawili się jako obrońcy przed (w domyśle: żydowską) agresją. Mechanizm ten ma w Polsce bogatą tradycję. Joanna Tokarska-Bakir, badaczka przedwojennych i powojennych pogromów na Żydach w Polsce, stawia tezę, że każdy pogrom rozpoczynał się od pogłoski, że Żydzi zrobili coś przeciwko chrześcijanom: sprofanowali hostię, porwali chrześcijańskie dziecko, zbezcześcili kościół (Tokarska-Bakir, 2008, 2012). Wystarczy wspomnieć pogrom kielecki z 1946 r.: bezpośrednim impulsem do niego było kłamstwo chłopca, który wrócił do domu po kilkudniowej nie- 
obecności, że spóźnił się, bo Żydzi zamknęli go w piwnicy. Kłamstwo to odwoływało się do klasycznego scenariusza „blood libel” - o chrześcijańskim dziecku, które Żydzi porywają, by upuścić z niego krew potrzebną do żydowskich rytuałów. Chłopiec został przez dorosłych zaprowadzony na milicję w celu złożenia takiego zeznania.

I jeszcze jeden historyczny kontekst zdarzenia: wyrzucanie z lokalu „za żydowskość" i deklaracja, że jakiś lokal jest „polski” lub „katolicki” to głośne echo polskiego przedwojnia. „Bojkot ekonomiczny" Żydów - hasło obecne w programie Narodowej Demokracji od 1907 roku i egzekwowane przez bojówki tej partii, w praktyce regularna przemoc wobec Żydów - miał wiele form (Rudnicki, 2008). W latach 30. przemoc ta nabrała charakteru rozporządzeń prawnych. Zakazano handlu w niedzielę, co dla Żydów utrzymujących się z handlu oznaczało dwa dni bez zarobku. Samorządy przenosiły dni targowe na soboty, by Żydzi nie mogli brać w nich udziału. Stowarzyszenia kupiecko-przemysłowe odmawiały przyjmowania Żydów. Banki odmawiały udzielania Żydom kredytów. Zwolennicy Narodowej Demokracji napadali na sklepy i stragany żydowskie, niszczyli żydowskie warsztaty. Zastraszali ludzi, którzy chcieli od Żydów kupować. Piętnowano osoby, które sprzedały Żydom ziemię lub dom, wywieszając na ulicach ich nekrologi i tym samym symbolicznie je uśmiercając. Wreszcie - i tu nawiązuję do zdarzenia w Cafe Foksal - w 1937 roku Ministerstwo Przemysłu i Handlu nakazało umieszczać na szyldach sklepów i warsztatów pełne imię i nazwisko właściciela (Ogonowski, 2012). Było to prawnym usankcjonowaniem praktyki wywieszania na lokalach tabliczek „to sklep chrześcijański”, „to lokal polski". Praktyka ta miała charakter ostentacyjnie antysemicki: miała zniechęcić Żydów do korzystania z takich lokalów i była jednocześnie zaproszeniem dla entuzjastów bojkotu ekonomicznego Żydów. Deklaracja „to jest bar katolicki” oznaczała groźbę pod adresem Żydów i nieoficjalny zakaz wstępu dla nich.

\section{Wiarygodność, płeć, świadek}

Wracam do 2017 roku. Wiarygodność pierwszego opisu zdarzeń - jedynego, w którym mowa o antysemityzmie - została podważona przy pomocy stereotypów genderowych. Za ich sprawą kobiety postrzegane są jako osoby kierujące się emocjami, które nie potrafią racjonalnie ocenić sytuacji. Autorka bloga została zdeprecjonowana jako ktoś, kto przesadza, nadinterpretowuje, jest przewrażliwiony. Ponieważ historię opisała kobieta, a przedmiotem jej opisu było zachowanie innej kobiety (barmanki), media jak mantrę zaczęły powtarzać sformułowanie: „emocje wzięły górę”. W polskiej kulturze kłótnie między kobietami są motywem komediowo-satyrycznym. Doczekały się nawet dedykowanego im, pogardliwego określenia: 
magiel. Magiel to "babski harmider", którego nie należy traktować poważnie. Stąd, jak sądzę, wziął się męski „świadek": by obiektywnie rozsądzić, co tak naprawdę się zdarzyło.

Świadek to także kategoria bogato reprezentowana w polskim dyskursie o Żydach. "Świadek" zrobił w Polsce zawrotną karierę jako termin najbardziej adekwatny do opisu sytuacji Polaków podczas Zagłady. Dyskursywna produkcja świadka (zwanego często „biernym”) w polskiej historiografii i w literaturze zaczęła się w Polsce już podczas wojny (Kann, 2003; M. B. [Szymanowski], 2003), czyli na długo przed tym, gdy Raul Hilberg zaproponował trójpodział na sprawców, świadków i ofiary (Hilberg, 2007). W świetle wiedzy o postawach i zachowaniach Polaków podczas Zagłady, zgromadzonej i upublicznionej już w latach 40., nie da się obronić tezy, że Polacy byli świadkami (Andrzejewski, 1945; Andrzejewski i in., 1947; Borowski, 1948; Janicka \& Żukowski, 2016; Nałkowska, 1946). Ale polski świadek to w polskim dyskursie także ktoś, kto - w przeciwieństwie do Żydów reprezentujących punkt widzenia patrykularny, a więc wybrakowany, niepełny - widzi więcej, jest bezstronny, dzięki niezaangażowaniu w sprawę zyskuje rangę zewnętrznego oka, eksperta. Narracje jednostek określanych mianem polskich świadków Zagłady przeciwstawiane są do dzisiaj narracjom świadków żydowskich. Świadków rzekomo zbyt uprzedzonych, zbyt rozemocjonowanych, zbyt stronniczych. Widać tutaj ciekawą paralelę do dyskursu mizoginicznego. Narracje żydowskie, traktujące między innymi o przemocy antysemickiej Polaków, pozycjonowane są - i w ten sposób pozbawiane wiarygodności - tak, jak narracje kobiece. Tymczasem świadectwa tych, którzy są przedmiotem opisu - Polaków pozycjonowane są jako wiarygodne, zbilansowane i rozstrzygające.

W pozbawieniu autorki bloga wiarygodności wzięła także udział policja. Ponieważ przyjechała ona na miejsce zdarzenia, była potem proszona przez media o informacje. Policjanci powtarzali, że: 1. mężczyźni wyproszeni z baru byli pijani; 2 . nie było widać, by mężczyźni ci ponieśli jakiekolwiek obrażenia cielesne; 3. choć rzekomo poszkodowani, mężczyźni nie wnieśli oskarżenia; 4. personel baru miał prawo wyprosić gości, bo jest to lokal prywatny (Bet \& Jankowska, 2017). O kobiecie, która wezwała policję i która opisała zdarzenie, w wypowiedziach policjantów nie było śladu.

\section{Rozjemcy i pojednanie}

Mamy więc kobiece słowo autorki bloga przeciwko kobiecemu słowu barmanki, mamy samozwańczego, męskiego „świadka”, który potwierdza wersję barmanki, mamy właścicielkę klubu, która staje w obronie barmanki, bo barmanka stanęła w obronie poszkodowanych chrześcijan, mamy policję, która prezentuje sprawę jako efekt pijaństwa gości i mamy media, 
które definiują sprawę jako „nagonkę na Cafe Foksal”. Mamy wreszcie internautów, którzy teraz już masowo stają w obronie Cafe Foksal, gratulują kawiarni i deklarują, że będą jej wiernymi klientami. Dlaczego? Bo Cafe Foksal przeciwstawiło się żydowskiej dyktaturze, bo wreszcie ktoś przełamał polityczną poprawność i powiedział prawdę, bo trzeba dbać o dobre imię Polski, Polaków i katolików, bo nagonka na Cafe Foksal to element żydowskiego spisku. Głosy internautów w obronie Cafe Foksal są wypowiadane w języku otwarcie antysemickim i nacjonalistycznym, Cafe Foksal staje się bohaterem tzw. młodzieży patriotycznej (celowo nie mówię: młodzieży prawicowej, bo patriotyzm czyni ten zbiór dużo większym) (Bernaciak \& Zimny, 2017; Cafe Foksal, b.d.; Rogowski, 2017). Kawiarnia nie wykonuje żadnego gestu dystansu wobec rzeszy nowych fanów.

I wtedy na scenę wkraczają rozjemcy. Osoby, które weszły w rolę ambasadorów pojednania i pojednanie to specyficznie zdefiniowały. Mogły one wejść w tę rolę, ponieważ dysponowały specyficznym kapitałem symbolicznym, a zarazem - jak to zazwyczaj z kapitałami bywa - wejście w rolę rozjemców kapitał ten pomnożyło.

Rozjemca pierwszy to Mikołaj Lizut. Dziennikarz i redaktor "Gazety Wyborczej” od 1994 roku. Reprezentował prawicowe skrzydło redaktorów "Gazety Wyborczej”, zorientowane pro-katolicko. Dzisiaj pracuje w radiu Tok Fm należącym do tego samego koncernu medialnego co "Gazeta Wyborcza".

Tu niezbędny jest zapowiadany już przypis o społecznym postrzeganiu "Gazety Wyborczej”, zwanej przez jej wrogów „Gazetą Koszerną". Jedni z tego żartują, inni traktują to na poważnie, jeszcze inni to udowadniają, ale wszyscy w Polsce wiedzą, że "Gazeta Wyborcza” ma etykietę "gazety żydowskiej”. Ma to ją kompromitować, ośmieszać lub demonizować, a nade wszystko ma ją to pozbawiać wiarygodności - jako medium stronniczego. To właśnie dlatego podczas incydentu w Cafe Foksal osoby, które stanęły w obronie barmanki, krzyczały do blogerki i jej przyjaciół: „Idźcie się poskarżyć do Michnika”. Żydowskość „Wyborczej” uzasadniana jest dwojako: tym, że Adam Michnik pochodzi z rodziny żydowskiej i tym, że na łamach tej gazety wielokrotnie dyskutowano kwestię polskiego antysemityzmu.

Od początku jego politycznego zaangażowania argument przeciwko Adamowi Michnikowi, że jest Żydem, zatem nie ma prawa reprezentować Polaków i nie jest godzien zaufania - podnosiła wobec Michnika zarówno władza, jak i ta część opozycji, która miała charakter katolicko-narodowy. Z czasem część ta umacniała się i liczebnie, i symbolicznie. Adam Michnik, podobnie jak inni członkowie opozycji z żydowskich rodzin, był podejrzany. Jego polskość była i jest do dzisiaj egzaminowana, poddawana w wątpliwość lub po 
prostu negowana. Jego rola - redaktora naczelnego największego liberalnego dziennika w Polsce - łatwo wpisuje się w teorie spiskową o Żydach, którzy sprawując kontrolę nad informacją sprawują kontrolę nad społeczeństwem. Żydowskie pochodzenie, komuniści w rodzinie, zaangażowanie polityczne, sława opozycjonisty oraz „świecznikowa” funkcja po 1989 roku - wszystko to sprawia, że Adam Michnik jest niemal toposem kultury polskiej. W środowiskach prawicowych, a także na przykład w zdominowanym przez ruch narodowy ruchu kibicowskim, Michnik funkcjonuje jako symbol wszystkiego tego, co należy zniszczyć. Mowa nienawiści wobec tej jednej osoby na samych tylko forach internetowych wystarczyłaby za przedmiot sążnistej pracy.

A więc Mikołaj Lizut, prawa ręka Adama Michnika, jego uczeń, przyjaciel i współpracownik. Drugi rozjemca to Michael Schudrich, od 2004 roku naczelny rabin Polski przy Gminie Wyznaniowej Żydowskiej w Warszawie. Sądząc po jego publicznych wypowiedziach strategią przyjętą przez Michaela Schudricha jest przedstawianie Polski jako kraju dobrych relacji między Polakami i Żydami, opartych o wieloletnią tradycję przyjaźni i koegzystencji. Wydarzenia antysemickie Schudrich zazwyczaj komentuje jako wybryki chuliganów i wyjątki od reguły.

I trzeci rozjemca: Ryszard Schnepf, ambasador Polski w Stanach Zjednoczonych w latach 2012-2016. Schnepf ma publiczną tożsamość żydowską, a zarazem - jako ambasador w tak ważnym państwie jak Stany Zjednoczone - wysoką rangę w sferze publicznej.

5 stycznia, za pośrednictwem Facebooka, Mikołaj Lizut i Ryszard Schnepf zapraszają wszystkich na kieliszek wódki do Cafe Foksal, „w imię pojednania i zgody”. Warunkiem wzięcia udziału w akcji jest przyjście do Cafe Foksal w kipie. Media reklamują wydarzenie („Przyjadą do Cafe Foksal. Będą pili alkohol w jarmułkach”, 2017), informują, że wezmą w nim udział medialne sławy. Potem entuzjastycznie je opisują jako szczęśliwe zakończenie nieszczęśliwego nieporozumienia (Karpieszuk, 2017). Do akcji przyłącza się właścicielka klubu obiecując, że także postawi gościom jedną kolejkę. Inicjatywa ma na celu udowodnić, że autorka bloga nie miała racji, bo Cafe Foksal to miejsce przyjazne i tolerancyjne. Akcja zostaje okrzyknięta sukcesem.

Już tego samego wieczora media opublikowały zdjęcia, na których mężczyźni w kipach i właścicielka baru wznoszą wódką toasty (T. J., 2017). Zdjęcia te stanowią obrazkową, komiksową wręcz wersję legendarnego w Polsce oświadczenia: „mam przyjaciela Żyda”. Deklaracja „przyjaźnię się z Żydami” to częstokroć w Polsce stosowane przez antysemitów alibi. Dowód, że ktoś taki nie może być przecież antysemitą, a zatem wszystko co mówi o Żydach to sama prawda. 


\section{Męskość i maska}

Warto przez chwilę zatrzymać się na charakterze tego performance'u. Po pierwsze ma on symbolicznie "męski” charakter: wspólne picie wódki to w Polsce silnie zmaskulinizowany rytuał zadzierzgania więzi między mężczyznami. Konwencjonalna forma male-bondingu. Kipa to tradycyjnie męskie nakrycie głowy. Bywa - choć bardzo rzadko - noszona przez kobiety, ale wtedy jest to zazwyczaj znak przynależności do judaizmu progresywnego. W Polsce mężczyźni noszący kipę na co dzień to widok rzadki, prawie niespotykany. Jednocześnie w polskiej ikonosferze kipa funkcjonuje jako symbol żydowskości - obok brody, pejsów, dużego nosa i trzymanych w ręku pieniędzy. „Żyd z pieniążkiem” - antysemicki obrazek wieszany $w$ domach jako talizman przynoszący pomyślność finansową - sprzedawany jest w całej Polsce w sklepach z pamiątkami, kioskach, kwiaciarniach, w galeriach sztuki i na bazarach. Przedstawiana na tych obrazkach postać nosi kapelusz albo kipę. Założenie kipy interpretować więc można jako gest auto-egzotyzacji. Przywdziania maski. Odegrania maskarady, co w tym wypadku oznacza wejście w rolę żydowską zaprojektowaną podług potrzeb chrześcijańskiego widza. O maskaradzie żydowskości jako formie antysemickiej przemocy pisał w 1939 roku poeta Władysław Szlengel w wierszu Maska Purymowa:

"Z waszej, Panowie łaski -

dla waszej wyższości i dumy -

nosimy rok cały maski

I nędzne, błazeńskie kostiumy..."

(Szlengel, 2013)

Nie chcę powiedzieć, że z definicji kipa jest przebraniem, a nie ubraniem. Chcę natomiast powiedzieć, że we współczesnym kontekście polskim należy ona do zestawu kostiumowego „polskiego Żyda”, a dzieje się tak między innymi za sprawą entuzjastycznie witanego przez nie-Żydów fenomenu tzw. odrodzenia życia żydowskiego w Polsce (Lehrer, 2013). W poświęconej Stanom Zjednoczonym książce Represent and Destroy. Rationalizing Violence in a New Racial Capitalism Jodie Melamed dowodzi, że za pomocą zarządzania wiedzą i specyficznego diagnozowania rasizmu, oficjalne antyrasizmy państwowe służyły w istocie utrzymaniu w mocy praktyk urasawiania i wielu form rasistowskiej przemocy (Melamed, 2011). Analogicznie, Jewish Revival in Poland, jak proces ten nazywają z entuzjazmem Amerykanie, interpretować można jako taką propozycję formuły żydowskości, która bezkolizyjnie 
wpisuje się w kulturę polską, nie burząc kultury tej antysemickiego komponentu. Rozliczne festiwale kultury żydowskiej, podczas których żydowskość sprowadzona zostaje albo do religijności, albo do estetyczno-folkowej fasady spod znaku specyficznego ubioru, muzyki, tańca, kuchni i zwyczajów, pozwalają Polakom poczuć się w roli życzliwie zainteresowanych „innymi” gospodarzy, którzy poprzez uczestnictwo w tego typu wydarzeniach praktykują moralnie słuszną postawę gościnności. Wiele podobnych inicjatyw nie tylko estetyzuje, ale także egzotyzuje Żydów, czyniąc z różnicy między Żydami a nie-Żydami przedmiot fascynacji i celebracji. Za sprawą dyskursu różnicy grupa większościowa zyskuje tożsamość tolerancyjnej, a Żydzi pozostają od niej w odległości, która nie narusza jej poczucia komfortu.

Choć inicjatorzy odrodzenia żydowskiego w Polsce chętnie sięgają do historii, zazwyczaj unikają takiego ujęcia dziejów żydowskich, które wskazywałoby na polski stosunek do Żydów jako jedną z kluczowych tych dziejów determinant. Żydowskie upodmiotowienie polityczne, żydowska problematyzacja relacji większość-mniejszość czyli relacji z Polakami, żydowskie roszczenie do równości czy wreszcie żydowskie ujawnienie przemocy - wszystko to nie mieści się w ramach zaproponowanych przez współczesne odrodzenie kultury żydowskiej w Polsce, gdyż psuje, a nie poprawia komfort grupy dominującej. Żydowskość może być tu co najwyżej specyficzną wiarą albo ciekawym stylem życia. Melamed dowodzi, że literatura rasowego liberalizmu wskazywała Afroamerykanom granice możliwych identyfikacji i problematyzacji ich doświadczenia biograficznego. Analogicznie, polskie Jewish Revival można traktować jak kulturową procedurę wyznaczania miejsca dla Żyda: podlegającym kontroli grupy większościowej procesem kształtowania dozwolonych tożsamości mniejszościowych. Dozwolonych, to znaczy takich, które tożsamość polską - kolektywną i indywidualną - pozostawiają nie tyle nienaruszoną, co umocnioną o komponent gotowości na wielokulturowość.

Właśnie tę gotowość potwierdzić miała akcja picia wódki w kipach w Cafe Foksal. Trudno nie zauważyć, że potwierdzenia tego dostarczyły osoby, które w oczach opinii publicznej reprezentują żydowskość. Organizatorzy „pojednania” weszli w rolę reprezentantów Żydów w Polsce i wykonali w ich imieniu gest: „nic się nie stało”. Niech wszyscy zobaczą, że bawimy się razem, pijemy razem, przyjaźnimy się, a przecież antysemici nie bawilibyśmy się, nie pili i nie przyjaźnili z nami. Ani dziennikarz, ani rabin, ani były ambasador Polski w USA nie mówili w swoim, indywidualnym imieniu, co sądzą o Cafe Foksal i o całej sprawie. Przeciwnie: zainicjowali akcję wspólnotową i jako taka zaistniała ona w mediach. Stworzyli podmiot zbiorowy i za jego sprawą przedstawili swoją inicjatywę jako reprezentatywną odpowiedź polskich Żydów na zarzuty o antysemityzm. Odpowiedź 
ta brzmi: „Nie oskarżamy Polaków o antysemityzm, przeciwnie: zaświadczamy, że traktują nas oni gościnnie". Jeśli, jak wspomniałam, Polacy, by uprawomocnić swoje antysemickie wypowiedzi, mówią "mam przyjaciela Żyda”, to akcja picia wódki w kipach była wejściem w rolę owego „przyjaciela”. Dostarczenia alibi z samego siebie.

Reakcja reprezentantów żydowskości na antysemityzm (celowo nie używam sformułowania reakcja żydowska, ponieważ w Polsce jednostki naznaczane są żydowskością niezależnie od własnej samoidentyfikacji) interesuje mnie tutaj dlatego, że ujawnia ona, moim zdaniem, jakie są warunki brzegowe stawiane Żydom w Polsce, by mogli oni być dopuszczeni do głosu i by głos ten został potraktowany jako reprezentatywny. Mówiąc bardziej dosadnie, uważam, że w reakcji tej widać skalę przemocy symbolicznej. ${ }^{2}$ Widać stopień subordynowania przez kulturę dominującą tych jednostek i grup, które pozostają w jej obrębie napiętnowane, toteż zmuszone są do nieustannego powtarzania „egzaminu z podporządkowania” (Żukowski, 2011).

\section{Ełk}

Co dzieje się, gdy ktoś tego egzaminu nie zdaje? Albo nie planuje do niego podejść? By odpowiedzieć na to pytanie, opis wydarzeń wokół Cafe Foksal należy uzupełnić informacją, co działo się dokładnie $w$ tym samym czasie w Ełku. W tę samą sylwestrową noc polskie media obiegła informacja, że „pod jednym z Kebabów w Ełku został zabity młody Polak” („Bardzo gorąco w Ełku. Wściekli ludzie demolują kebab i zabójstwie (VIDEO i ZDJĘCIA)”, 2017). O domniemanych sprawcach tego zabójstwa media pisały następująco: „Algierczyk”, „obcokrajowiec", , "cudzoziemiec", , imigranci z Maroko, Algierii i Tunezji”, „mężczyźni pochodzenia arabskiego", „Algierczyk z polskim paszportem”. A o barze w Ełku, pod którym zginął mężczyzna - „lokal prowadzony przez cudzoziemców” (acis, kch, bz, pszl, pch, \& dm, 2017; „Co się wydarzyło w Ełku (NAJWAŻNIEJSZE FAKTY)”, 2017; „Daniel zginął od ciosów nożem, areszt dla kucharza i właściciela baru z kebabem”, 2017; „Zabił 21-latka w Ełku. Ze łzami w oczach tłumaczył się przed kamerami", 2017). Z doniesień medialnych wynikało, że do baru Prince Kebab wszedł 21-letni mężczyzna, zabrał dwie butelki Coca-coli z lodówki i wyszedł nie płacąc. Nie ukrywał się z tym, przeciwnie, zrobił to demonstracyjnie. Kolega mężczyzny

\footnotetext{
${ }^{2}$ Kategorii przemoc symboliczna używam za Pierre'm Bourdieu jako terminu określającego internalizację podporządkowania i krzywd wynikających ze społecznych determinant. Mam tutaj na myśli przemoc, którą jednostka - za sprawą wdrożonych i ucieleśnionych mechanizmów podporządkowania kulturze dominującej - dokonuje na samej sobie, by poprawnie i skutecznie zreprodukować wzory owej kultury (Bourdieu, 2004).
} 
wrzucił do Prince Kebab racę. Za złodziejem wybiegło z lokalu dwóch jego pracowników. Jeden miał przy sobie nóż kuchenny. Użył go podczas bójki ze złodziejem, w efekcie czego złodziej doznał ran, które okazały się śmiertelne.

W ciągu następnych godzin pod pozorem upamiętnienia zabitego, koło baru zebrało się kilkaset osób, głównie młodych mężczyzn. Podczas zgromadzenia krzyczano hasła rasistowskie, islamofobiczne i przeciwko uchodźcom. Bar został zdemolowany. Policja użyła gazu pieprzowego i aresztowała 28 osób.

W medialnych opisach tych sytuacji i w komentarzach ekspertów szukających ich przyczyn nie padały słowa: rasizm i islamofobia. Jednocześnie te same media cały czas podkreślały, że sprawcami zabójstwa byli: Arabowie, Algierczyk, Tunezyjczyk, cudzoziemcy, a ofiarą - Polak. Prezydent Ełku wyraził zdziwienie, że do incydentu doszło, gdyż "nigdy wcześniej nie było informacji, aby w lokalu z kebabem prowadzonym przez obcokrajowców były jakieś problemy" (Ręczmin \& Andrukiewicz, 2017). Poproszony o komentarz do sprawy, polski Minister Spraw Wewnętrznych Mariusz Błaszczak powiedział: „w Polsce nie ma problemów społecznych, z jakimi mamy do czynienia na zachodzie Europy, gdzie mamy duże enklawy muzułmańskich emigrantów, którzy się nie integrują z pozostałą częścią społeczeństwa" (mart/sk, 2017). Pytany o zachowania protestujących pod barem, Błaszczak powiedział, że są one wyrazem „zupełnie zrozumiałych obaw ludzi” przed wydarzeniami takimi jak zamachy w Berlinie, Nicei i Brukseli (mart/sk, 2017).

Policja aresztowała trzech pracowników baru. Dwóm z nich nie postawiła zarzutów. Wypuszczając ich z aresztu przyznała im ochronę, bo mężczyznom groził lincz. Potem policja utajniła daty wizji lokalnych z udziałem jedynego aresztowanego, bo bała się, że dojdzie wówczas do zamieszek. Kilka godzin po tym, jak media obiegła informacja o "Polaku, który zginął pod kebabem”, w innej części Polski, w Lublinie, zdemolowano bar Superkebab. Sprawcy napisali na szybach lokalu: „Jebać ISIS”, „Fuck ISIS” i „Fuck Islam” (PB \& ECH, 2017).

3 stycznia media przedrukowały świadectwo mężczyzny, który był w barze 2 godziny przed zabójstwem ((ezio) \& AIP, 2017). Świadectwo - opublikowane wcześniej na Facebooku - zaczyna się od specyficznej autodeklaracji, która, jak sądzę, miała nadać mu charakter bezstronnej obserwacji i tym samym je uwiarygodnić: „Jestem zwolennikiem walki z terroryzmem, zatrzymywaniu i ograniczaniu napływu uchodźców z krajów arabskich. Stanowczo potępiam politykę Niemiec i Francji w tej sprawie. Jednakże jestem człowiekiem, który ma rozum i zmysły, które pozwalają mi patrzeć na sprawy tego typu obiektywnie 
i racjonalnie." Następnie świadek opisuje, że w barze znajdowało się kilku pijanych mężczyzn. Prawdopodobnie jeden z nich to później zabity Daniel R. Krzyczeli oni do pracowników baru: „Dawaj kurwo te jedzenie, tylko nie pluj, bo ci tym mordę wysmaruję” oraz "Ciapaku na kolana i do pana". Obsługa baru nie reagowała, choć, zdaniem świadka, widać było po niej zdenerwowanie.

Te dwie sytuacje - Cafe Foksal i Prince Kebab - a potem ich następstwa i ich omówienia medialne wydarzają się dokładnie w tym samym czasie. Czy odgrywa to rolę w wyborze strategii rozjemców z Warszawy? Czy ma to wpływ na fakt, że w ogóle na scenę wkraczają rozjemcy? Czy historia z Ełku zostaje potraktowana jako przestroga? Zły scenariusz, który może się powtórzyć w Warszawie, a zatem trzeba coś wymyślić, by sytuację uspokoić? Wydarzenia z Ełku i Lublina wydają mi się kontekstem „picia wódki z antysemitami", którego nie można pominąć.

\section{Rama wzajemności}

Ogłaszając sukces akcji „picia wódki w Cafe Foksal", Mikołaj Lizut podsumował: „Czasem po prostu ważna jest serdeczna rozmowa, bez zajadłości i uprzedzeń". „Żyjemy razem i powinniśmy się wzajemnie szanować" - to z kolei wezwanie Ryszarda Schnepfa („„Antysemityzm w Polsce jest jak nowotwór». Mikołaj Lizut i Ryszard Schnepf zapraszają do Cafe Foksal", 2017). Taka rama narracyjna - rama wzajemności - została natychmiast podchwycona przez innych komentatorów i przez media. Właścicielka Cafe

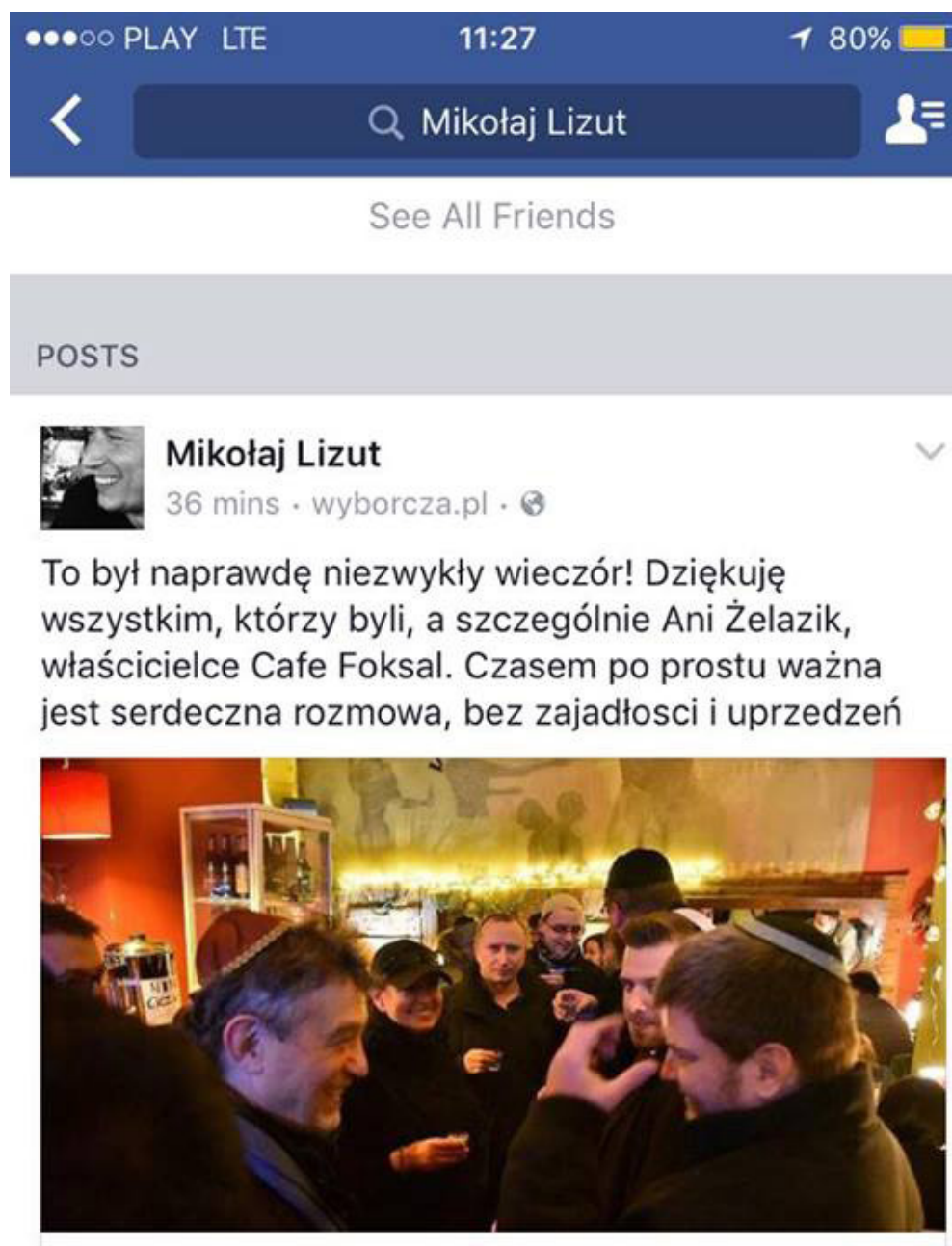

'Za przyjaźń i pojednanie'. Toast w kipach w Cafe Foksal

warszawa.wyborcza.pl

\section{$00: 22$}

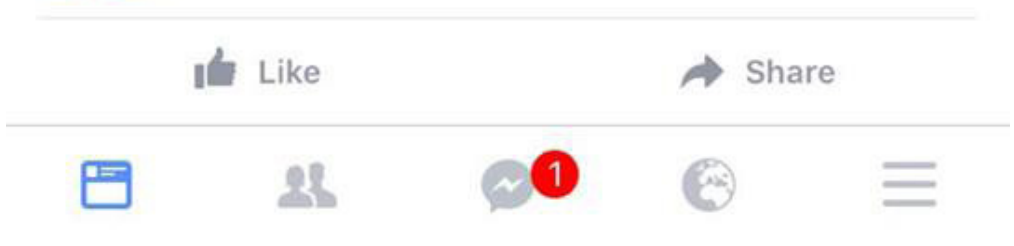


Foksal napisała, że akcja ta była „wbrew tym, którzy chcieli nas skłócić” (ej, 2017). W istocie rama wzajemności towarzyszyła sprawie od momentu, w którym do obiegu publicznego trafił wpis z bloga Gburrek.pl. Rama ta ma w polskim dyskursie wyjątkowo silną konstrukcję. Do jej budulca należą terminy takie jak: relacje polsko-żydowskie, stosunki polskie żydowskie i dialog polsko-żydowski, a także terminy stosowane w odniesieniu do historii, w szczególności zaś do dwudziestolecia międzywojennego: konflikt, potyczki, konkurencja

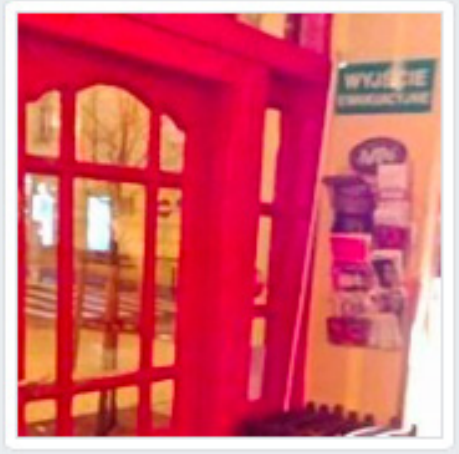

\section{Cafe Foksal}

(B) cafefoksal21

\section{Strona główna}

Informacje

Zdjęcia

Recenzje

Posty

Społeczność

Utwórz stronę

$$
\text { I Lubię to! ה Obserwuj } \rightarrow \text { Udostępnij } \quad \cdots
$$

Cafe Foksal dodał(a) nowe zdjęcia (3).

6 stycznia $\cdot \Theta$

Wieczorem w Cafe Foksal. Bardzo miły wieczór w towarzystwie kilkudziesięciu wspaniałych mężczyzn w kipach oraz wspaniałych kobiet $\cdot \cdot$ Dzięki za fajną inicjatywę i wbrew tym którzy chcieli nas skłócić. Pozdrawiamy i mamy nadzieje ze wszystko nas złączy! (-) Dobrej nocy! http://warszawawpigulce.pl/przyjada-do-cafe-foksal-beda-pi.../
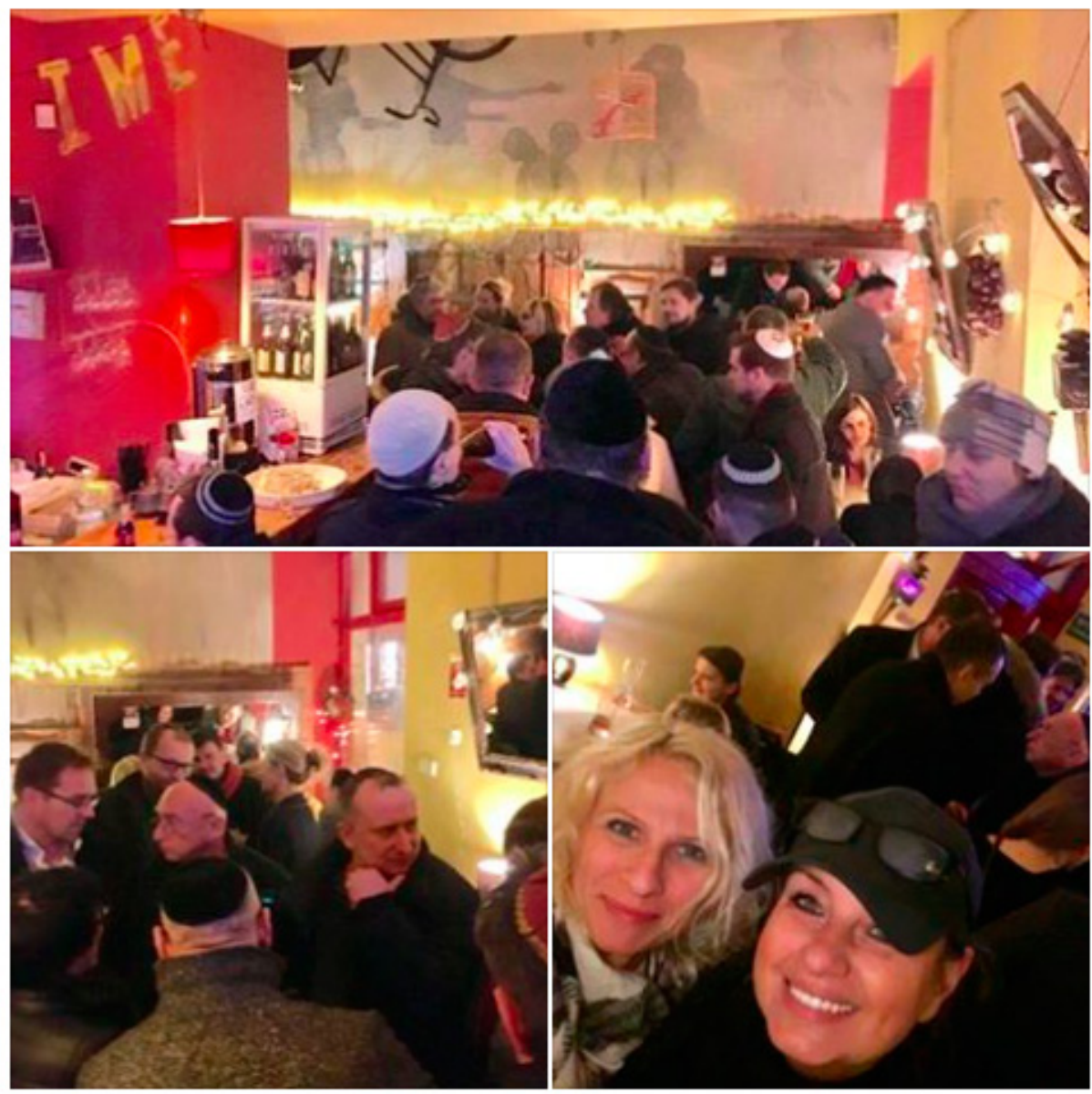

¿ubię to!

Komentarze

$\Leftrightarrow$ Udostępnij

6) 
ekonomiczna, nadreprezentacja. Wszystkie one tworzą taki obraz sytuacji, w której mamy do czynienia z dwoma równie silnymi, równie sprawczymi, równie upodmiotowionymi i cieszącymi się równą prawomocnością kulturową grupami: Polakami i Żydami. Na tym obrazie grupy te toczą ze sobą jakieś spory, walczą ze sobą i próbują się ze sobą dogadać. Jest to relacja partnerstwa i wzajemności - wzajemnych uprzedzeń i krzywd, ścierania się interesów i dogadywania się jak równy z równym.

Taka rama dyskursywna sprawia, że wypowiedź antysemicka i wypowiedź o antysemityzmie funkcjonują jako dwie równoprawne narracje, pomiędzy którymi należy znaleźć "złoty środek". W tej ramie konteksty, jakimi są: przemoc antysemicka, dynamika relacji większość-mniejszość, mechanizmy dominacji oraz antysemickie motywy kultury polskiej nie mają prawa zaistnieć. Z pola widzenia znika także przepaść między dobrowolnością a przymusowością zaangażowania w antysemicki spektakl. Różnica społecznego uplasowania podmiotów zaangażowanych w sprawę - (1) kogoś, kto posługuje się antysemityzmem, (2) kogoś, kto to zauważa i kto się temu sprzeciwia, (3) Żydów, którzy dziś w takich interakcjach pozostają raczej tworzywem, niż podmiotem - zostaje usunięta poza widzialność.

\section{Paradygmat tożsamości}

Zatrzymajmy się na chwilę przy Żydach jako tworzywie. Chodzi mi o sytuacje, w których antysemickie komunikaty nie są kierowane bezpośrednio do Żydów. Przykładem niech będą kibicowskie graffiti. Mury polskich miast - a zwłaszcza Krakowa i Łodzi - pełne są napisów z użyciem słowa „Żyd" i „Żydzi”. Określenia te mają charakter deprecjonującej, upokarzającej obelgi. Skierowane są najczęściej do kibiców przeciwnej drużyny, czasem pracowników służb mundurowych, rzadziej przedstawicieli władzy lokalnej lub państwowej. Kibice polscy nie mówią o Żydach ani do Żydów, lecz używają słowa „Żyd" jako oczywistego przekleństwa. W efekcie ich język nie zostaje rozpoznany jako antysemicki nie tylko przez cynicznych komentatorów (wielokrotnie słyszałam, że dopatrując się w hasłach typu „jebać Żydów maczetami" antysemityzmu wykazuję niewiedzę o slangu kibiców, bo nie o Żydów tu chodzi), ale także przez polskie prawo.

W przepisach polskiego prawa są trzy artykuły odnośnie mowy nienawiści. Artykuł 216 Kodeksu Karnego: „kto znieważa inną osobę w jej obecności albo choćby pod jej nieobecność, lecz publicznie lub w zamiarze, aby zniewaga do osoby tej dotarła, podlega grzywnie albo karze ograniczenia wolności”. Artykuł 190 Kodeksu Karnego: „kto grozi innej 
osobie popełnieniem przestępstwa na jej szkodę lub szkodę osoby najbliższej, jeżeli groźba wzbudza w zagrożonym uzasadnioną obawę, że będzie spełniona, podlega grzywnie, karze ograniczenia wolności albo pozbawienia wolności do lat 2". I artykuł 257 Kodeksu Karnego: „kto publicznie znieważa grupę ludności albo poszczególną osobę z powodu jej przynależności narodowej, etnicznej, rasowej, wyznaniowej albo z powodu jej bezwyznaniowości lub z takich powodów narusza nietykalność cielesną innej osoby, podlega karze pozbawienia wolności do lat $3^{\prime \prime}{ }^{3}$ Zatem popełniasz przestępstwo tylko wtedy, gdy obrażasz kogoś, bo jest Żydem. Jeśli ktoś, do kogo kierujesz obraźliwe słowa, nie jest Żydem, to mówiąc do niego "ty Żydzie” nie działasz wbrew prawu. Prawo nie przewiduje trzeciej opcji: że obrażasz nie Żyda, lecz Żydem.

Paradygmat tożsamości rządzący polskim prawem skutkuje kuriozalnymi wyrokami sądów w sprawach o mowę nienawiści. Co znamienne, paradygmat ten dominuje także w badaniach sondażowych na temat antysemityzmu, których autorzy formułują pytania o stosunek do Żyda. Na przykładzie kibicowskiego graffiti widać tymczasem, że antysemityzm to raczej kod kultury polskiej, w którym Żyd jest narzędziem komunikacji. Jej tworzywem, ale nie jej celem i nie jej adresatem. Słowem-znakiem rozpoznawanym jako obraźliwe. Paradygmat tożsamości powoduje przesunięcie interpretacyjne, które więcej zasłania niż wyjaśnia.

Sprawdziłam jak to działa w praktyce niejako przypadkiem. W styczniu 2016 roku poszłam na policję zgłosić, że ktoś na bloku, w którym mieszkam, napisał „Żydzi Won”. Nie pytając mnie o to, policjant przyjmujący zgłoszenie wpisał do protokołu, że jestem „osobą narodowości żydowskiej". Kiedy zwróciłam mu uwagę, że nic takiego nie powiedziałam, zapytał: „to jest pani, czy nie jest?". Przez następne 10 minut powtarzałam uparcie dopytującemu i coraz bardziej zirytowanemu policjantowi, że odmawiam odpowiedzi na to pytanie. On przekonywał mnie, że musi to wiedzieć, bo od tego zależy mój status w sprawie: poszkodowanej albo świadka. Powiedziałam: „czuję się tym napisem poszkodowana”. Na co on triumfalnie wykrzyknął: „Czyli jest pani Żydówką!” To właśnie nazywam paradygmatem tożsamości. Myślę, że właśnie ten mechanizm spowodował, że autorka bloga ostatecznie nie wniosła oskarżenia. W jej opowieści nie ma mowy o tym, czy jest ona Żydówką, czy nie. Domyślam się, że to pytanie zadali jej policjanci. A następnie poinstruowali, że jeśli nie odpowie twierdząco, nie mają jak przyjąć od niej zgłoszenia.

\footnotetext{
3 Kodeks karny - ustawa z dnia 6 czerwca 1997 roku. Podaję za: „Mowa nienawiści: Kodeks karny - ustawa z dnia 6 czerwca 1997 r.", b.d.
} 


\section{Epilog}

2 lipca 2017 r. poszłam z kolegą do Cafe Foksal. O godzinie 14 byliśmy tam jedynymi gośćmi. Właścicielka (rozpoznałam ją dzięki zdjęciom w gazetach ze stycznia) sprzątała jeszcze po nocnej imprezie. Bar jest mały, optycznie powiększać go mają rozwieszone wszędzie lustra. $\mathrm{Na}$ jednym z takich luster były:

1. Wlepka sławiąca Żołnierzy Wyklętych - narodową partyzantkę powojenną, odpowiedzialną za czystki etniczne, w tym zbrodnie antysemickie. Jeszcze 10 lat temu Żołnierze Wyklęci w głównym nurcie kultury polskiej uchodzili zbyt kontrowersyjnych. Z ich kultem obnosiła się wyłącznie skrajna prawica. Dziś są oficjalnymi bohaterami narodowymi.

2. Wlepka sławiąca Józefa Kurasia, pseudonim „Ogień", najpierw walczącego w Armii Krajowej, po wojnie tzw. żołnierza wyklętego. Zbrodnie antysemickie „Ognia” były na tyle liczne i na tyle spektakularne, że nawet historycy z Instytutu Pamięci Narodowej uważają go za postać problematyczną.„Ogień" od lat jest bohaterem skrajnie prawicowych bojówek.

3. Wlepka sławiąca Danutę Siedzikównę, pseudonim „Inka” - tzw. żołnierkę wyklętą, której kult krzewi skrajnie prawicowa partia Ruch Narodowy i sympatyzujący z nią kibice piłkarscy.

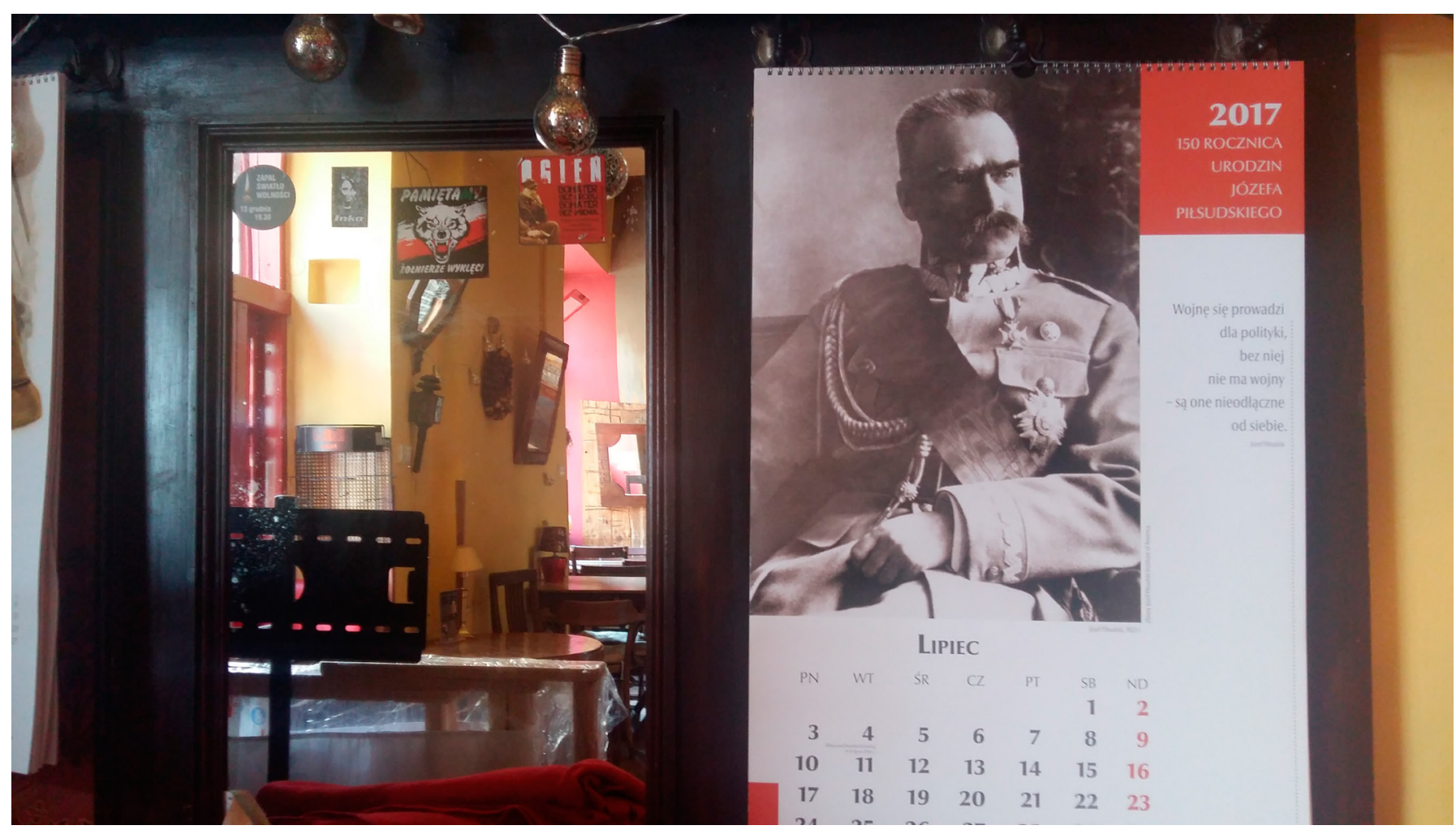


4. Wlepka "Zapal światło wolności 13 grudnia" (chodzi o rok 2016) akcji Instytutu Pamięci Narodowej, objętej patronatem przez prezydenta Andrzeja Dudę. Rocznica stanu wojennego co roku wykorzystywana jest przez rozmaite ugrupowania od centrowych po skrajnie prawicowe - do zwoływania demonstracji. W 2016 roku akcja „Zapal światło wolności" przeobraziła się w wiec poparcia dla partii obecnie rządzącej jako jedynej, która naprawdę chce rozliczyć się z komunizmem.

W lokalu wiszą trzy dużych rozmiarów kalendarze. Pierwszy przedstawia Józefa Piłsudskiego. Drugi - wspomnianą już „Inkę”. Trzeci to reklama Biura Bezpieczeństwa Narodowego. Na lodówce z napojami stoją flagi polska i amerykańska. W lokalu nie ma innych politycznych deklaracji.

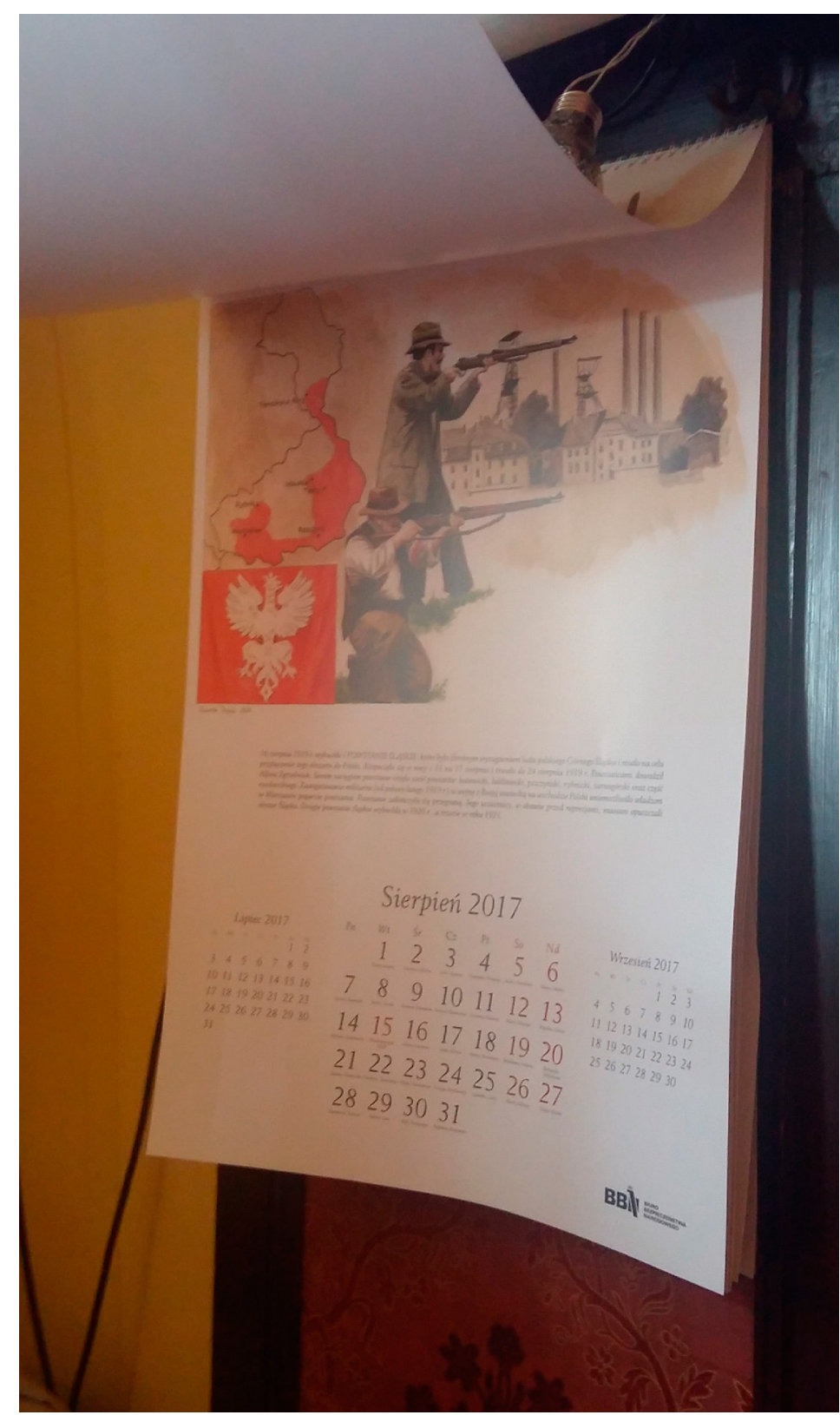

\section{Bibliografia}

acis, kch, bz, pszl, pch, \& dm. (2017, styczeń 1). Tunezyjczyk z zarzutem zabójstwa 21-latka z Ełku. Pobrano 5 listopada 2017, z https://www.tvp.info/28436620/tunezyjczyk-z-zarzutem -zabojstwa-21latka-z-elku

Andrzejewski, J. (1945). Noc: Opowiadania. Warszawa: Czytelnik.

Andrzejewski, J., i in. (1947). Martwa fala: Zbiór artykułów o antysemityzmie. Warszawa: Spółdzielnia Wydawnicza "Wiedza”.

"Antysemityzm w Polsce jest jak nowotwór". Mikołaj Lizut i Ryszard Schnepf zapraszają do Cafe Foksal. (2017, styczeń 5). Pobrano 5 listopada 2017, z http://wawalove.pl/Antysemityzm-w-Polsce -jest-jak-nowotwor-Mikolaj-Lizut-i-Ryszard-Schnepf-zapraszaja-do-Cafe-Foksal-a25216/30 
Bardzo gorąco w Ełku. Wściekli ludzie demolują kebab i zabójstwie (VIDEO i ZDJĘCIA). (2017, styczeń 1). Pobrano 5 listopada 2017, z http://pikio.pl/zadyma-pod-kebabem-w-elku-tlum -zaczal-demolowac-lokal-zdjecia-video/

Bernaciak, N., \& Zimny, A. (2017, styczeń 4). W obronie Cafe Foksal. STOP Obrażaniu Chrześcijan w Warszawie! [Wydarzenie na Facebooku]. Pobrano 4 listopada 2017, z https://www.facebook. com/events/1029165760560127/

Bet, N., \& Jankowska, E. (2017, styczeń 4). Seria nienawistnych telefonów po awanturze w Cafe Foksal. Poszło o rozmowę o Żydach. Metro Warszawa. Pobrano 5 listopada 2017, z http:// metrowarszawa.gazeta.pl/metrowarszawa/7,141637,21198231,seria-nienawistnych-telefonow -po-awanturze-w-cafe-foksal.html

Borowski, T. (1948). Pożegnanie z Marią. W T. Borowski, Pożegnanie z Marią i inne opowiadania. Warszawa: PIW.

Bourdieu, P. (2004). Męska dominacja (L. Kopciewicz, Tłum.). Warszawa: Oficyna Naukowa.

Cafe Foksal [Strona na Facebooku]. (b.d.). Pobrano 4 listopada 2017, z https://www.facebook .com/cafefoksal21/

Co się wydarzyło w Ełku (NAJWAŻNIEJSZE FAKTY). (2017, styczeń 3). Pobrano 5 listopada 2017, z http://www.newsweek.pl/polska/co-sie-wydarzylo-w-elku-najwazniejsze-fakty -synteza,artykuly,402990,1.html

Daniel zginął od ciosów nożem, areszt dla kucharza i właściciela baru z kebabem. (2017, styczeń 3). Pobrano 5 listopada 2017, z https://www.tvn24.pl/pomorze,42/elk-algierczyk-i -marokanczyk-zwolnieni-do-domu,704136.html

ej. (2017, styczeń 6). Pojednanie w Cafe Foksal? Po głośnej awanturze o rozmowę o Żydach wypili razem wódeczkę. Metro Warszawa. Pobrano 5 listopada 2017, z http://metrowarszawa .gazeta.pl/metrowarszawa/7,141637,21210636,pojednanie-w-cafe-foksal-po-glosnej-awanturze -o-rozmowe-o-zydach.html

(ezio), \& AIP. (2017, styczeń 3). Był w Prince Kebab kilka godzin przed tragedią. Klienci mieli mówić: „Ciapaku na kolana i do pana”. Pobrano 5 listopada 2017, z http://www.wspolczesna .pl/wiadomosci/elk/a/byl-w-prince-kebab-kilka-godzin-przed-tragedia-klienci-mieli-mowic -ciapaku-na-kolana-i-do-pana,11652758/

Hilberg, R. (2007). Sprawcy, ofiary, świadkowie: Zagłada Żydów 1933-1945 (J. Giebułtowski, Tłum.). Warszawa: Stowarzyszenie Centrum Badań nad Zagładą Żydów.

Janicka, E., \& Żukowski, T. (2016). Przemoc filosemicka: Nowe polskie narracje o Żydach po roku 2000. Warszawa: Wydawnictwo Instytutu Badań Literackich PAN.

Kann, M. (2003). Na oczach świata. W W. Bartoszewski (Red.), Tryptyk polsko-żydowski. Warszawa: Rada Ochrony Pamięci Walk i Męczeństwa.

Karpieszuk, W. (2017, styczeń 5). „Za przyjaźń i pojednanie”. Toast w kipach w Cafe Foksal. Pobrano 4 listopada 2017, z http://warszawa.wyborcza.pl/warszawa/1,34862,21209517,za -przyjazn-i-pojednanie-toast-w-kipach-w-cafe-foksal.html 
„Katolicyzm” po polsku. Jak zostaliśmy zaatakowani w centrum Warszawy przez obsługę Cafe Foksal. (2016). Pobrano 1 lipca 2017, z http://gburrek.pl/2017/01/03/katolicyzm-po-polsku-jak -zostalismy-zaatakowani-w-centrum-warszawy-przez-obsluge-cafe-foksal/

Lehrer, E. T. (2013). Jewish Poland revisited: Heritage tourism in unquiet places. Bloomington: Indiana University Press.

M. B. [Szymanowski, A.]. (2003). Likwidacja ghetta warszawskiego. Reportaż. W W. Bartoszewski (Red.), Tryptyk polsko-żydowski. Warszawa: Rada Ochrony Pamięci Walk i Męczeństwa.

mart/sk. (2017, styczeń 2). „W Polsce jest bezpiecznie w porównaniu z tym, co się dzieje u naszych sąsiadów". Pobrano 5 listopada 2017, z https://www.tvn24.pl/wiadomosci-z-kraju,3 /blaszczak-o-zamieszkach-w-elku,703901.html

Melamed, J. (2011). Represent and destroy: Rationalizing violence in a new racial capitalism. Minneapolis: University of Minnesota Press. https://doi.org/10.5749/minnesota/9780816674244.001.0001

Mowa nienawiści: Kodeks karny - ustawa z dnia 6 czerwca 1997 r. (b.d.). Pobrano 5 listopada 2017, z http://www.mowanienawisci.info/post/kodeks-karny-ustawa-z-dnia-6-czerwca $-1997-r /$

Nałkowska, Z. (1946). Medaliony. Warszawa: Czytelnik.

Ogonowski, J. (2012). Sytuacja prawna Żydów w Rzeczypospolitej Polskiej 1918-1939: Prawa cywilne i polityczne. Warszawa: Żydowski Instytut Historyczny.

PB, \& ECH. (2017, styczeń 1). Atak na lokal Hindusa w Lublinie. Wandale zaatakowali w sylwestrową noc. Pobrano 5 listopada 2017, z http://lubin.naszemiasto.pl/artykul/atak-na-lokal -hindusa-w-lubinie-wandale-zaatakowali-w,3968493,artgal,t,id,tm.html

Przyjadą do Cafe Foksal. Będą pili alkohol w jarmułkach. (2017, styczeń 5). Pobrano 4 listopada 2017, z https://warszawawpigulce.pl/przyjada-do-cafe-foksal-beda-pili-alkohol-w-jarmulkach/

Ręczmin, M., \& Andrukiewicz, T. (2017). Prezydent Ełku Tomasz Andrukiewicz dla WP o zamieszkach przed Prince Kebab: to dla nas szok. Pobrano 5 listopada 2017, z https://wiadomosci. wp.pl/prezydent-elku-tomasz-andrukiewicz-dla-wp-o-zamieszkach-przed-prince-kebab-todla-nas-szok-6075599547843713a

Rogowski, B. (2017, styczeń 3). Bojkot Cafe Foksal 2017 - dość przemocy i antysemityzmu! [Wydarzenie na Facebooku]. Pobrano 4 listopada 2017, z https://www.facebook.com /events/359150067783884/

Rudnicki, S. (2008). Równi, ale niezupełnie. Warszawa: Biblioteka Midrasza.

Szlengel, W. (2013). Maska Purymowa. W M. Stańczuk (Red.), Władysław Szlengel, poeta nieznany: Wybór tekstów (s. 105). Warszawa: Świat Książki.

T. J. (2017, styczeń 5). Wypiliśmy w Cafe Foksal "kieliszek pojednania”. „To piękny polski gest”. Pobrano 4 listopada 2017, z http://wawalove.pl/Wypilismy-w-Cafe-Foksal-kieliszek-pojednania -To-piekny-polski-gest-a25226

Tokarska-Bakir, J. (2008). Legendy o krwi. Warszawa: WAB.

Tokarska-Bakir, J. (2012). Okrzyki pogromowe: Szkice z antropologii historycznej 1939-1946. Wołowiec: Czarne. 
Zabił 21-latka w Ełku. Ze łzami w oczach tłumaczył się przed kamerami. (2017, styczeń 4). Pobrano 5 listopada 2017, z http://www.fakt.pl/wydarzenia/polska/elk-zabil-21-latka-w-elku -tlumaczy-sie-ze-Izami-w-oczach/snyf8ly

Zawadzka, A. (2012). Polska walcząca. W W. Wilczyk, Święta wojna. Łódź: Atlas Sztuki.

Żukowski, T. (2011, lipiec 4). Obrzeża Zagłady: Grzeczny Polak, grzeczny Żyd. Gazeta Wyborcza.

\section{Drinking vodka with anti-Semites. A case study of 'Polish-Jewish relations' today}

This text analyzes the events that occurred between December 31, 2016 and January 6, 2017, namely the 'scandal' at the Café Foksal pub in Warsaw and its ramifications, as well as the simultaneous attacks on the Prince Kebab shop in Ełk. Both events were local or, many would venture to say, marginal. It is not my intention to attribute great importance to them. I rather treat them as meaningful case studies which exemplify how anti-Semitism operates in Polish culture at present and, probably more importantly, the roadblock encountered when problematizing anti-Semitism. These allegedly insignificant events from the turn of 2016-2017 are an excellent illustration of the conditions that Jews and other individuals perceived to be non-Polish have to accept in order to ensure relative safety to themselves. I discuss these events as a certain spectacle, whose actors played either the roles they chose or the only roles available to them (perpetrator, victim, bystander, and mediator). I also suggest viewing these events from the point of view of certain elements of Polish history.

\section{Keywords:}

anti-Semitism, bystander, Café Foksal, Mikołaj Lizut, Gazeta Wyborcza, Ełk

\section{Pijąc wódkę z antysemitami. Case study „relacji polsko-żydowskich” współcześnie}

Tekst stanowi analizę zdarzeń, które miały miejsce między 31 grudnia 2016 a 6 stycznia 2017: „afery” w warszawskiej Cafe Foksal i jej następstw oraz dziejących się równolegle ataków na bar Prince Kebab w Ełku. Zdarzeń o charakterze lokalnym, a wielu powiedziałoby także: marginalnym. Moim celem nie jest przypisywanie im wielkiego znaczenia. Traktuję je natomiast jako symptomatyczne case study, na przykładzie którego widać funkcjonowanie antysemityzmu w polskiej kulturze dzisiaj i - co może bardziej istotne - blokady, na jakie napotyka jego problematyzowanie. Te pozornie nieistotne zdarzenia z przełomu 2016-2017 znakomicie pokazują, na jakie warunki muszą przystać Żydzi i inne jednostki postrzegane jako nie-polskie, by zapewnić sobie względne bezpieczeństwo. Omawiam te zdarzenia jako swoisty spektakl, podczas którego określone podmioty wchodziły w wybrane lub w jedyne 
dostępne im role (sprawcy, ofiary, świadka, rozjemcy). Proponuję także, by na zdarzenia te spojrzeć przez pryzmat wybranych elementów polskiej historii.

\section{Słowa kluczowe:}

antysemityzm, świadek, Cafe Foksal, Mikołaj Lizut, Gazeta Wyborcza, Ełk

\section{Citation:}

Zawadzka, A. (2018). Pijąc wódkę z antysemitami. Case study „relacji polsko-żydowskich” współcześnie. Adeptus, 2018(11). https://doi.org/10.11649/a.1672 